Vol. 2, No. 2, 2015

\author{
O. S. Lemishovska \\ $\mathrm{PhD}$ of Economic Sciences, \\ Lviv Polytechnic National University
}

\title{
METHODICAL BASES OF FUNDAMENTAL WORKS ON ACCOUNTING BY L. PACHOLI AND JA. YMPYN: COMPARATIVE ASPECT
}

\begin{abstract}
There are analyzed the conceptual and methodical principles of accounting described in the fundamental accounting literature in general and there is made the direct comparison of methodical arsenals in works of L. Pacholi and Ja. Ympyn. The relationships between these works on accounting are defined and the the major provisions described in them are compared.

In any sphere of activity, there always exists the first (basic, fundamental) published work, which represents the scientific and applied nature of a certain subject area of knowledge. It is considered that in the sphere of accounting such work is the development related to the organization of accounting by L. Pacholi presented in his book "Treatise on Accounts and Records".
\end{abstract}

The book of L. Pacholi contained rather exhaustive description of all ways of accounting of all kinds of trade operations, which caused its impact on the results of scientific work of many authors in the sphere of accounting and bookkeeping. Almost all adherers to the compliance with the methodological principles and organization of accounting provided in the work of L. Pacholi, saw his main achievements in the detailed compilation of the accounting practice of that period, which he formulated in 17 basic rules of accounting. According to the research of C. Keil, Italian authors of works on bookkeeping to the middle of the $17^{\text {th }}$ century were completely under the influence of L. Pacholi's works [1, p. 52], remaining on the position of personification. Thus, it is considered that contribution of these authors was generally connected with specification and development of separate provisions of L. Pacholi. In general, in the area of historical research into formation and development of accounting there are provided many arguments on the fact that at that time there were many research and development works on accounting, in which lots of valuable and independent provisions were formulated, in spite of the fact that they were based on the Treatise.

A Netherlandish scientist Ja. Ympyn became the most famous follower and distributor of L. Pacholi's ideas. His work published in Flemish and French in 1543, contained the basic ideas disclosed by L. Pacholi. Despite the relationship of the basic foundations of both works, researchers differently interpret their comparative aspects. This fact makes such component of historical research as formation and development of the scientific principles of accounting relevant.

Key words: history of the accounting, development of the accounting, accounting literature.

Analysis of recent research and publications. For a number of objective reasons and established approaches to performing thematic research in the subject area of formation of accounting as scientific and applied activity, scientists, who are conducting research of history of accounting on interrelation of the works considered in the article, are limited to the generalized comparison of methodical techniques in these research and development works. Thus, for example, F. Butynets considers "material of the treatise of Ja. Ympyn more systematized and updated" [2, p. 58]. O. Galagan, relying on research of $\mathrm{K}$. Kheil, claims that "the work of Ja. Ympyn is a recomposed translation, and in some places a close translation of Pacholi's work" [3, p. 73]. Opposite to the given estimates, Ya. Sokolov makes a conclusion that "Ja. Ympyn significantly updated ideas of L. Pacholi" [4, p. 83]. These facts quite distinctly show the ambiguity of scientists' positions concerning the level of compilation of these works.

In general, despite the above-mentioned and some other scientific research works, in the theory of accounting now there are no ambiguous conclusions concerning relationship and the level of interrelations of content and methodical statements in the literary works of L. Pacholi and Ja. Ympyn, that is why the subject considered remains relevant.

The purposes of article are establishment of the conceptual orientation of the basic accounting literature in general and direct comparison of methodical arsenals in the research and development works of L. Pacholi and Ja. Ympyn, specification of connections between these accounting works and disclosure, in the comparative aspect, the basic provisions, which they cover. 


\section{O. S. Lemishovska}

Presentation of the main research material. As in any field of people activities the transfer of bookkeeping to the higher level is connected with new developments in this sphere, or with development of already existing scientific and applied knowledge. In the Middle Ages the book of L. Pacholi "Treatise on Accounts and Records" had significant impact on the development of accounting, and its printed variant was published in 1494 in Venice, shortly after the invention of book printing by Gutenberg (1436). Almost in all research works on history of accounting L. Pacholi (1445-1515) is called the founder of double entry bookkeeping, attributing its "invention" and description to him. But the question whether he was really the inventor of double entry still remains debatable.

The debatability of such statements in research works on history of emergence of accounting as a scientific and applied discipline follows from the fact that L. Pacholi himself specified that in his work he would adhere to the existing Venetian method of accounting. Based on this, many scientists consider that L. Pacholi just described and systematized what was already known in bookkeeping practice at that time [1-3]. Besides, by emphasizing the use of Venetian method of accounting in his work, L. Pacholi indirectly pointed out that other methods of accounting were also used at that time. However, this fact fragmentally mentioned by him, doesn't give enough grounds to state that these methods were based on double-entry bookkeeping [5].

The works of Netherlandish scientist Ja. Ympyn present considerable interest for the researchers of the history of accounting. His first book was published in the Flemish language in 1543 in Antwerpen. In the same year, his work was published also in French. The importance of the Ja. Ympyn's work publication is also proved, for example, by the fact that in Russia the translation of this book under the title "the Key of Commerce" was published (1783) much earlier than the translation of L. Pacioli's Treatise was printed (1893).

Research and development work of Ja. Ympyn connected with double entry bookkeeping consists of theoretical and practical parts. The first part is representing a manual, which consists of 29 chap- ters, the second part contains examples of Inventory, Journal, Double and Simple Registers.

As to the format of Ja. Ympyn's work, it is necessary to note that in 1547 the English translation of his Treatise was published but without the practical part of the book.

Generally, all three editions of the book contained the introduction, content of which revealed the necessity of obtaining scientific knowledge and art of bookkeeping, mastering practical maintenance of accounting books according Italian method. Besides this, according to the author's statement, the book was intended "to restore in memory what the outstanding scientists wrote about this method" [6, p. 138]. Besides, according to the author's statement, the book was intended for "recalling the facts about which the outstanding scientists wrote". Among such scientists he notes A. Tagliente and others, who published their works and distributed them in the Italian and German languages. The critical analysis of the content of these works stressed that "they wrote so shortly and darkly that only few people or even nobody obtained knowledge from this science, unless to study it being taught by the authors themselves or by the teachers teaching his science for certain payment" $[6$, p. 152]. In his opinion, the offered development works should have provided greater clearness both in the methodical plan and in the technology of conducting accounting records. Seeking to overcome these shortcomings, he noted: "for this reason I got acquainted in details with this science to extend it further" [6, p. 154].

Despite these facts, to form the content of his work Ja. Ympyn used the results of the work of J. Paulo - an Italian, who "worked for the distribution of this science more than any other scientist before, trying to allow people to acquire knowledge" [3, p. 74]. There is no information about the identity of the above-named Italian in the history of the accounting thought. According to K. Cale's research, "the mentioned J.Paulo could be a pupil of L. Pacholi, one of the sons of a rich merchant who stayed in the monasteries where the L.Pacholi was writing his works in Italian" [1, p. 36].

It is appropriate to allocate and systematize the basic provisions, analyzing the contents of the well-known works of L. Pacholi and the Flemish edition of research and development work of Ja. Ympyn (Table 1). 
Contents of the books by L. Pacholi and Ja. Ympyn [6, 7]

\begin{tabular}{|c|c|c|c|}
\hline \multicolumn{2}{|r|}{ Contents of the book by L. Pacholi } & \multicolumn{2}{|r|}{ Contents of the book by Ja. Ympyn } \\
\hline \multicolumn{2}{|r|}{1} & \multicolumn{2}{|r|}{2} \\
\hline 1 & $\begin{array}{l}\text { Things that are necessary to the good merchant and the method } \\
\text { of keeping a ledger its journal, in venice and elsewhere }\end{array}$ & 1 & $\begin{array}{l}\text { The contentes of this treatise, and to whom it } \\
\text { shalbe proffitable, and what is requisite to a } \\
\text { marchant. }\end{array}$ \\
\hline 2 & $\begin{array}{l}\text { First part of this treatise, which is called inventory - what } \\
\text { inventory is, and how to make it. }\end{array}$ & 2 & $\begin{array}{l}\text { How this present worke is deuided in twoo } \\
\text { partes, and the firste is the inuentory, and what } \\
\text { that is, and how to precede in thesame }\end{array}$ \\
\hline 3 & Example of an inventory with all its formal requirements & 3 & $\begin{array}{l}\text { Of the seconde parte of this treatise called } \\
\text { disposicion or orderyng of the worke, and } \\
\text { what bokes are requisite, and how thei shal be } \\
\text { called }\end{array}$ \\
\hline 4 & Very useful admonition and good advice to the good merchant & 4 & $\begin{array}{l}\text { The maner of the memoriall boke, and who } \\
\text { maie write therin }\end{array}$ \\
\hline 5 & $\begin{array}{l}\text { Second principal part of this treatise named disposition - what } \\
\text { is understood by it - what it consists of in business, and the } \\
\text { three principal books of the merchant }\end{array}$ & 5 & $\begin{array}{l}\text { How bookes be lawfully aucthorised, and the } \\
\text { order taken for reconyng bokes in some places } \\
\text { in italy, muche to be praised }\end{array}$ \\
\hline 6 & Of the first book, which is called memoriale book & 6 & How to enter a parcell in the memoriall boke \\
\hline 7 & $\begin{array}{l}\text { Of the manner in which in many places mercantile books are } \\
\text { authenticated, why and by whom }\end{array}$ & 7 & $\begin{array}{l}\text { Of the diuersitee of bargainyng, whiche } \\
\text { happen at the least nyne sondery waies }\end{array}$ \\
\hline 8 & $\begin{array}{l}\text { How entries should be made in the said memorandum book, } \\
\text { and examples of the same }\end{array}$ & 8 & $\begin{array}{l}\text { Of the seconde boke called the jornall, what } \\
\text { thing it is, and how it ought to be kept }\end{array}$ \\
\hline 9 & $\begin{array}{l}\text { Of nine ways in which the merchant usually buys, and the } \\
\text { goods which it is more or less necessary to buy on time }\end{array}$ & 9 & $\begin{array}{l}\text { Of certain termes and woordes that shalbe } \\
\text { vsed bothe in the jornall and greate boke }\end{array}$ \\
\hline 10 & $\begin{array}{l}\text { The second important mercantile book which is called journal, } \\
\text { what it is, and now it should be kept in an orderly way }\end{array}$ & 10 & $\begin{array}{l}\text { Of the third boke called in italy, el quadarno, } \\
\text { and with us the great boke. And of the a. } \\
\text { B. C. Belongyng to the said boke }\end{array}$ \\
\hline 11 & $\begin{array}{l}\text { The two expressions used in the journal, especially in venice, } \\
\text { the one called "per", and the other "a" and what is understood } \\
\text { by them }\end{array}$ & 11 & $\begin{array}{l}\text { How ye shall set oner the parcelles of your } \\
\text { journal into the great boke and wherfore eche } \\
\text { parcel once write in the journal, must be twise } \\
\text { written in the greate boke }\end{array}$ \\
\hline 12 & $\begin{array}{l}\text { How the entry should be made into the journal by means of the } \\
\text { debit and the credit, with many examples. The two other } \\
\text { expressions used in the ledger, the one called "cash," and the } \\
\text { other "capital," and what should be understood by them }\end{array}$ & 12 & $\begin{array}{l}\text { How in the greate boke, the place muche or } \\
\text { little shalbee leaft, of the disposicion of the } \\
\text { parcelles, and how to remoue them }\end{array}$ \\
\hline 13 & $\begin{array}{l}\text { Third and last principal mercantile book called the ledger. How } \\
\text { it is to be kept. Its alphabet (index), and how this can be kept } \\
\text { single and double }\end{array}$ & 13 & $\begin{array}{l}\text { How to remedy and amend parcelles euill } \\
\text { written in the boke by negligence }\end{array}$ \\
\hline 14 & $\begin{array}{l}\text { How the entries should be transferred from the journal into the } \\
\text { ledger and why, for each entry of the journal, you have to make } \\
\text { two in the ledger; how entries in the journal should be cancel- } \\
\text { led. The two numbers of the pages of the ledger which are } \\
\text { placed in the margin of each entry and why }\end{array}$ & 14 & $\begin{array}{l}\text { Of the change of the yere, and how to geue } \\
\text { accompte to the debitor, and to come to a rest }\end{array}$ \\
\hline 15 & $\begin{array}{l}\text { The way in which the cash and capital entries should be posted in } \\
\text { The ledger in the debit and the credit. The date which at the top } \\
\text { Of the page is written down according to the ancient use. } \\
\text { Changing of the same. How to divide the space on the pages for } \\
\text { small and large accounts as the business requires }\end{array}$ & 15 & $\begin{array}{l}\text { How to kepe a reconnyng of a retaylyngshop, } \\
\text { that is to saie, to knowe what proffite com- } \\
\text { meth thereby by sale made for ready money, } \\
\text { loane or otherwise }\end{array}$ \\
\hline 16 & $\begin{array}{l}\text { How the entries relative to the merchandise op which one is } \\
\text { possessed according to his inventory, or otherwise, should be } \\
\text { made in the ledger both in the debit and the credit }\end{array}$ & 16 & $\begin{array}{l}\text { Of another accompt vsed in the boke, whiche } \\
\text { the italians call pro and damno that we call } \\
\text { gaynes and losse }\end{array}$ \\
\hline 17 & $\begin{array}{l}\text { How to keep accounts with public offices, and why. The } \\
\text { camera de L'impresti (municipal loan bank) in venice, which is } \\
\text { managed by sestieri (districts) }\end{array}$ & 17 & How to kepe accompt of barteryng \\
\hline
\end{tabular}




\section{O. S. Lemishovska}

\begin{tabular}{|c|c|c|c|}
\hline \multicolumn{2}{|r|}{1} & \multicolumn{2}{|r|}{2} \\
\hline 18 & $\begin{array}{l}\text { How you should keep your accounts with the office of the } \\
\text { messetaria in venice. How to make entries pertaining thereto in } \\
\text { the memorandum book, journal and ledger, and about loans }\end{array}$ & 18 & $\begin{array}{l}\text { How to ordre and entre into the boke, the seue- } \\
\text { rall accomptes of a compaignie or parteners }\end{array}$ \\
\hline 19 & $\begin{array}{l}\text { How we should make the entries in our principal books of the } \\
\text { payments that we have to make either by draft or through the } \\
\text { bank }\end{array}$ & 19 & $\begin{array}{l}\text { How to enter into your boke, wares shipped or } \\
\text { sent into any countree, and charges of thesame }\end{array}$ \\
\hline 20 & $\begin{array}{l}\text { Entries for the well-known and peculiar mercantile customs of } \\
\text { trading and partnership, etc. How they should be entered in the } \\
\text { mercantile books. First : simple tradings, then complex tradings } \\
\text { and examples of entries for them in the memorandum book, } \\
\text { journal and ledger }\end{array}$ & 20 & $\begin{array}{l}\text { Of exchange, and billes of exchange a goodly } \\
\text { instruccion how thei should be entred into the } \\
\text { bok }\end{array}$ \\
\hline 21 & $\begin{array}{l}\text { The other well-known entry called partnership. How it should } \\
\text { be written in each book in the proper manner }\end{array}$ & 21 & $\begin{array}{l}\text { The manor how to write in the boke, poundes, } \\
\text { shelynges and pence }\end{array}$ \\
\hline 22 & $\begin{array}{l}\text { Regarding the entries of every kind of expense, as for instance } \\
\text { household expenses, ordinary or extraordinary, mercantile } \\
\text { expenses, wages of clerks and apprentices. How they should be } \\
\text { entered in the books. }\end{array}$ & 22 & $\begin{array}{l}\text { What ordre is to be kept with billes, euidences, } \\
\text { actes, processes, instrumentes, protestacions, } \\
\text { sentences, memories and letters missiues }\end{array}$ \\
\hline 23 & $\begin{array}{l}\text { In what manner the accounts of a store should be kept. Whether } \\
\text { the store is under your care or under the care of other people. } \\
\text { How the accounts should be entered in the authentic books of } \\
\text { the owner separate from those of the store itself }\end{array}$ & 23 & $\begin{array}{l}\text { What maner of bokes are requisite to be had to } \\
\text { avrite in suche thynges as is not mete to be } \\
\text { written in the jornall, nor in the great boke }\end{array}$ \\
\hline 24 & $\begin{array}{l}\text { How you should keep in the journal and ledger. The accounts } \\
\text { with the bank. What is understood by them. Bills op exchange- } \\
\text { whether you deal with a bank or yourself are a banker. Receipts } \\
\text { for drafts - what is understood by them and why they are made } \\
\text { out in duplicate }\end{array}$ & 24 & $\begin{array}{l}\text { How to close vp your boke when it is full, and } \\
\text { to remoue the restes of parcelles from one } \\
\text { place to another, and to knowe what proffite } \\
\text { ye haue doen in all the tyme ye vsed thesame } \\
\text { boke }\end{array}$ \\
\hline 25 & $\begin{array}{l}\text { Another account which is usually kept in the ledger, called } \\
\text { income and expenses, for which often a separate book is used, } \\
\text { and why }\end{array}$ & 25 & $\begin{array}{l}\text { How to make the ballaunce of this boke and } \\
\text { all other, and how to serch the fautes if the } \\
\text { ballaunce agree not }\end{array}$ \\
\hline 26 & $\begin{array}{l}\text { How entries should be made in mercantile books relative to } \\
\text { trips which you conduct yourself or you entrust to other people, } \\
\text { and the two ledgers resulting there from }\end{array}$ & 26 & $\begin{array}{l}\text { How to cary the parcelles of the old boke into } \\
\text { the new, and where to write them while the } \\
\text { balaunce is in makyng and till the parcelles be } \\
\text { entered into the new boke, and how to intitle } \\
\text { the newe boke }\end{array}$ \\
\hline 27 & $\begin{array}{l}\text { Another well-known account named profit and loss, or profit } \\
\text { and deficit. How it should be kept in the ledger and why it is } \\
\text { not kept in the journal as the other accounts }\end{array}$ & 27 & $\begin{array}{l}\text { A certain instruccion how to kepe an accompt } \\
\text { of diuerse affaires }\end{array}$ \\
\hline 28 & $\begin{array}{l}\text { How full accounts in the ledger should be carried forward and } \\
\text { the place to which they must be transferred so that no } \\
\text { crookedness can be practiced in the ledger }\end{array}$ & 28 & $\begin{array}{l}\text { A declaracio of certain thynges whiche are } \\
\text { specially to be noted }\end{array}$ \\
\hline 29 & $\begin{array}{l}\text { How to change the year in the ledger between two successive } \\
\text { entries in case the books are not closed every year }\end{array}$ & 29 & $\begin{array}{l}\text { The conclusion of the boke of informacion } \\
\text { very necessary to be lerned if ye desire to kepe } \\
\text { areconyng after the best maner, and what } \\
\text { daungers and losses maie folowe by not } \\
\text { kepyng a perfight boke }\end{array}$ \\
\hline \multicolumn{4}{|c|}{ Contents of the book by L. Pacioli } \\
\hline 30 & \multicolumn{3}{|c|}{$\begin{array}{l}\text { How an abstract or statement of an account should be made to a debtor who might request it, or for your employer in } \\
\text { case you are manager or commissioner of the administration of his property }\end{array}$} \\
\hline 31 & \multicolumn{3}{|c|}{$\begin{array}{l}\text { How to take out one or more entries which by mistake you might have entered in a different place from the right one, } \\
\text { which may happen through absentmindedness. }\end{array}$} \\
\hline 32 & \multicolumn{3}{|c|}{ How the balance of the ledger is made and how the accounts of an old ledger are transferred to a new one } \\
\hline 33 & \multicolumn{3}{|c|}{$\begin{array}{l}\text { How the transactions which might occur while you balance your books should be recorded, and how in the old books } \\
\text { no entry should be made or changed during that time, and reasons why }\end{array}$} \\
\hline 34 & \multicolumn{3}{|c|}{$\begin{array}{l}\text { How all the accounts of the old ledger should be closed and why. About the grand totals of the debits and credits, } \\
\text { which is the preparation of the trial balance }\end{array}$} \\
\hline 35 & \multicolumn{3}{|c|}{$\begin{array}{l}\text { How and in what order papers should be kept, such as manuscripts, family letters, policies, processes, judgments and } \\
\text { other instruments of writing and the record book of important letters }\end{array}$} \\
\hline 36 & \multicolumn{3}{|l|}{ Summary op the rules and ways for keeping a ledger } \\
\hline
\end{tabular}


It is possible to come to certain conclusions on the basis of the information of the comparative table.

First of all, we will note that chapter 2 of the Treatise of L. Pacholi describes inventory more from the technical point of view and a technique of its drawing up. For profound understanding of the sense of this technique, Ja. Ympyn is giving the main postulates of the book of the predecessor, defines the essence of the used conceptual framework "Thus now to procede to the firste parte of this worke called the Inuentory, whiche is properly as muche to saie as a discripcion of sondery goodes, substancially written $\&$ valued, making mencio of all the goodes debters and countre debters, to any person dewe of right" [6, p. 152]. Separately in the third and fourth parts L. Pacholi gives example of drawing up of the stock and forms instructions on its drawing up (similar examples are absent in the work of Ja. Ympyn). But in the related section Ja. Ympyn discloses the content of the second part of the Treatise called the disposition. Here instructions are provided about what books are to be kept and their names. This section according to the contents is similar the $5^{\text {th }}$ part of the Treatise, however, from the methodical point of view it can be characterized as substantially more reasonable.

In the $5^{\text {th }}$ part of the Treatise, L. Pacholi doesn't disclose and interpret in details the fragment from its title "...what is understood as disposition...", but explains the meaning of three books: Memorial, Journal and Main. In the content-similar presentation (section 3) Ja. Ympyn gives the term "disposition" as a mechanism, orders and execution of the current and future affairs of a merchant. Providing analytical information about books, Ja. Ympin in details describes their formats, number of pages, indicates the need of attachments of the register-alphabet to them. In the $4^{\text {th }}$ chapter of the work Ja. Ympyn describes Memorial, adhering to the position of L. Pacholi, stated in the $6^{\text {th }}$ chapter of his Treatise.

The attention is deserved by the $7^{\text {th }}$ chapter of Ja.Ympyn, which corresponds the $9^{\text {th }}$ chapter of L. Pacholi's work. In it nine ways of purchasing goods are described: in cash, on credit, exchange for goods, partially in cash, the rest in exchange, partially in cash, the rest on credit, partially in exchange, partial credit, transmission, partial transmission, partially-credit, partially transmission, the rest in exchange. At this, the last ways of purchasing goods are presented by Ja. Ympyn in more details. In the eighth and tenth sections the approaches of both authors are similar as to the fact that the entries should be made in Journal: primarily the entries are inventory articles, the records in which can be abbreviated using the terms "Rer" and "A" (debitor and creditor).

Section nine of the Ja. Ympyn's work being akin to the $11^{\text {th }}$ chapter of L. Pacholi's work is devoted to the interpretation of the terms of the debtor ("Per") and lender ("A"). J. Impin explains them as follows: "So shall you by these two first wordes used by the Italians, that is to say, Par and A. Understande that this worde Par, be tokeneth the debtor. And this terme A. the creditor" [6, p. 155]. L. Pacholi interprets these expressions as: "“Per" indicates a debitor, one or more as the case may be, and " $\mathrm{A}$ " indicates a creditor, one or more as the case may be" [7, p. 43].

Next Ja. Ympyn explains the concept of "Cassa" and "Capital", details of which L. Pacholi describes very briefly in the $12^{\text {th }}$ chapter. Detailing the term "Cassa" Ja. Ympyn writes : "An then understandyng that we meane by this worde Casse, the chest that kepeth the redy money, and by the worde Cassier he that kepeth the money, we maie procede in our woorke and saie. It is also requisite and very mete that all parcelles entred into the Jornall at the charge of the Cassier, that is to saie of hym that kepeth the money, that thei be entred with his owne hande, or at the least that he subscribe and affirme that thei came to hys handes and kepynge, for no man maie charge his Cassier but by his hand, as shal be shewed in the exemplary of the Jornall" [6, p. 156].

Concerning Capital, he writes: "The other worde, the Italians call the Capital, that ist to saie, the Stocke or principall that the Marchant began withall, whiche came ether by bequest of his frendes or parentes, or by gift, or by mariage or els by Executorship as well of wares as money" [6, p. 156].

The information provided in the $10^{\text {th }}, 11^{\text {th }}$ and $12^{\text {th }}$ chapters of Ja.Ympyn's work in its content coincides with the L. Pacholi's ideas outlined in the $13^{\text {th, }} 14^{\text {th }}$ and $15^{\text {th }}$ chapters of his work and deals with the methods of keeping the Main, the Register to it, procedures of transferring articles from a Journal into the Main, records and the techniques of transferring them.

The $13^{\text {th }}$ chapter of the Ja. Ympyn's work defines procedures for correcting faulty records in the books. In its content the statements are similar to those in the $31^{\text {th }}$ chapter of L. Pacholi's work. In the fourteenth chapter Ja. Ympyn highlights the procedure of making changes in the general ledger in case it is not terminated every year. L. Pacholi writes about this in the $29^{\text {th }}$ and $30^{\text {th }}$ chapters.

In his research and development work (chapter 16) Ja. Ympyn writes about the account 


\section{O. S. Lemishovska}

"Profits and losses". He doesn't justify the definition of this term, and only in the practical part of the Flemish and French editions he explains in detail the formations of this account using examples. In the $17^{\text {th }}$ chapter Ja. Ympyn describes exchange operations, providing like L. Pacholi (in the $20^{\text {th }}$ chapter), three ways of exchange: goods for goods; part goods, part money; the rest credit.

But for the above mentioned aspects of research and development work it is worth to note that the $19^{\text {th }}$ chapter concerns sale of goods to other cities and rising expenses in this regard, and also deals with the household expenses. L. Pacholi writes about this in chapters 22-23 of his book. The difference in presenting information by these authors lies in the fact that Ja. Ympyn considers concrete expenses on goods by means of similar account, and indirect expenses he refers to the account "The maintenance of household".

Conclusions. Research and development work of Ja. Ympyn, which was mainly based on the L. Pacholi's Treatise, still can be attributed to those which have deepened methodological developments of theoretical and applied content, brought an additional impulse in the development of the accounting thought, and as a result, in the practice of organizing and maintaining the bookkeeping. The main distinctions of the considered works concerned accounts, registers and interpretation of terminology.

The essential difference of these two works concerns closing the accounts. So, Ja. Ympyn suggested closing accounts by means of the account "Balance", unlike L. Pacholi, who conducted closing accounts through the account "Capital". The author offered a new way of closing accounts "Goods": after carrying out inventory the author recommended to credit concrete analytical accounts and to debit synthetic account of the rest of "Goods", to close this account by debiting the account of "Balance".

In the part connected with bookkeeping, novelty can be provided through different approaches to the order of maintaining the Memorial. From the point of view of Ja. Ympyn, such bookkeeping process should include, besides the habitual facts of economic activity, being the subject of accounting, future facts as well (how many and what goods should be purchased) and reference information (where and how many sheets have been sent). In the work of Ja.Ympyn there are recommendations about maintaining accumulative sheets. For realization of control, Ja.Ympyn recommended maintaining the separate journal, in which to write down the minor and other expenses during the month and to enter only the monthly summary into the Journal. It became the foundation of the operational accounting of commodity turnover.

In general it can be noted that in his work Ja. Ympyn was primarily trying to avoid direct copying of insufficiently defined terms and concepts, giving them specific content, but while maintaining the essence and spirit of the original work. Critical reevaluation of L. Pacholi's ideas enabled Ja.Ympyn "to shed light" on some procedural issues that weren't clearly outlined in the Treatise. So, development and research work of Ja. Ympyn can be considered as having laid the fundamental basis for further works on the development of double-entry bookkeeping, allowed significantly enrich comments to the Treatise. In addition, in the Ja. Ympyn's work, as the barely noticeable thread, there appears the thought of moral aspects of economic activity and its accounting provision ("rules of trade affairs and the proper journalizing"), they being the factors, which are now called "social responsibility" and "correct formation of the formalized accounting information".

\section{References}

1. Kheil K. P. Über einige ältere Bearbeitungen zur Geschichte des Buchhaltungs von Luca Pacioli / K. P. Kheil // Ein Beitrage zur Geschichte der Buchhaltung. - Prague : Bursik \& Kohout), 1896. - 64 p.

2. Butynets F. F. History of Accounting: in 2 parts. P. $1 /$ F. F. Butynets // Educating Manual. - Zhytomyr : PE "Ruta", 2001. - 512 p.

3. Galagan A. M. Accounting in its historical development / A. M. Galagan. - M.-L : State Publishing House, 1927. $-172 p$.

4. Soklov Ya. V. Accounting: from sources up to nowadays: manual for higher education institutions / Ya. V. Soklov. - M. : YUNITI, 1996. - 638 p.

5. Pacioli L. Treatise on Accounts and Records / L. Pacioli; under the editorship of Ya. V. Sokolov. - M. : Finances and statistics, 2001. - 368 p.

6. Bauer O. Memoirs to the History of Accounting and Monuments of Sacred Old Times / O. Bauer. - M. : Society "Printing-Office of S. P. Yakovlev", 1911. - 370 p.

7. Geijsbeek J. Ancient dooble-entry bookkeeping. Lucas Pacioli's treatise (A. D. 1494 - the earliest known writer on bookkeeping) reproduced and translated with reproductions and abstract from Manzoni, Pietra, Mainardi, Ympyn, Stevin and Dafforne. - Denver, Col., 1914. - $182 p$.

8. Ruver R. How occurred double entry accounting. Development of accounting before Luca Pacioli according to the account books of merchants of Middle Ages / A. Mukhin translated from English. - M. : Gosfinizdat, 1958. - 218p. 